\title{
ECHINODERM IMMUNOLOGY: BACTERIAL CLEARANCE BY THE SEA URCHIN STRONGYLOCENTROTUS PURPURATUS
}

\author{
MARY A. YUI AND CHRISTOPHER J. BAYNE
}

Department of Zoology, Oregon State University, Corvallis, Oregon 97331

\begin{abstract}
Characteristics of bacterial clearance were investigated in the purple sea urchin, Strongylocentrotus purpuratus (Echinodermata: Echinoidea). Primary clearance kinetics were determined for three bacteria, a marine Gram negative motile rod, a marine Gram positive non-motile rod, and a Gram negative freshwater fish pathogen, Aeromonas salmonicida. Clearance kinetics differed for each of the three bacteria. Secondary clearance rates were not significantly different from primary clearance rates for any of the three bacteria, regardless of the time interval between inoculations (9-21 days), implying a probable absence of immunologic memory. During primary clearance, total coelomocyte counts declined $93 \%$ by 90 min post injection. All four coelomocyte types declined, however the relative proportions of each type changed during the six-hour sampling period. In cell-free coelomic fluid, viable counts of marine bacteria declined, with different kinetics for the two species. Viable counts in sea water controls did not change. Declines in viable counts may be due to bactericidal activity and/or agglutination, although bacterial agglutination was not observed.
\end{abstract}

\section{INTRODUCTION}

Despite recent advances (reviewed by Cooper, 1976; Manning and Turner, 1976; Marchalonis, 1977; Hildemann et al., 1981), the phylogeny of immunity remains obscure. In particular, the mechanisms of invertebrate immunity are diverse, and many are poorly understood. The phylogenetic position of echinoderms makes them pivotal to the understanding of the phylogeny of immunity and the evolution of vertebrate immunity.

Allogeneic transplantation studies have shown that memory and specificity, two important characteristics of vertebrate immune responses, are possessed by echinoderms (Karp and Hildemann, 1976; Coffaro and Hinegardner, 1977; Coffaro, 1980), as well as by members of other invertebrate phyla (sponges, Hildemann $e t$ al., 1979; cnidarians, Hildemann et al., 1977; annelids, Cooper, 1970). Any role of memory and specificity in invertebrate internal defenses to potentially infectious agents has yet to be identified.

In this study, we sought to determine whether the echinoderm, Strongylocentrotus purpuratus, exhibits memory or altered reactivity on secondary contact with biologically relevant antigens, namely bacteria. Additionally, because the coelomic fluid of healthy echinoderms is generally aseptic (Bang and Lemma, 1962; Unkles, 1977; Kaneshiro and Karp, 1980), and few studies have been made on the characteristics and mechanisms of bacterial clearance in echinoderms (Johnson, 1969a, b; Johnson et al., 1970; Johnson and Chapman, 1971; Wardlaw and Unkles, 1978),

Received 11 April 1983; accepted 25 July 1983. 
we also studied some of the in vivo and in vitro primary interactions between echinoderm coelomocytes and cell-free coelomic fluid and bacteria.

\section{MATERIALS AND METHODS}

\section{Collection and maintenance of animals}

Strongylocentrotus purpuratus (80-150 g) were hand collected from intertidal surge channels at Yaquina Head, Newport, Oregon where the species is abundant. Care was taken to avoid damaging the urchins during collection and transportation to the 22,700 liter recirculating sea water system at Oregon State University in Corvallis, $70 \mathrm{~km}$ away. Water temperatures were $12-15^{\circ} \mathrm{C}$, comparable to coastal temperatures. Urchins were fed macroalgae ad libitum.

\section{Isolation and culture of bacteria}

One Gram negative motile rod and one Gram positive non-motile rod were isolated from the coelomic fluid (CF) of moribund sea urchins. Selection was based on growth characteristics (rate of growth, colony color and morphology). All bacteria were grown in marine broth 2216E (Difco Laboratories), enriched with peptone $\left(5 \mathrm{~g}^{-1}\right)$ and yeast extract $\left(3 \mathrm{~g}^{-1}\right)$. Nutrient agar $(1 \%)$ in marine broth was used for pour plate viable counts. For each experiment, bacteria were inoculated into fresh, enriched broth in triple baffle, side-arm flasks and grown at room temperature (20$23^{\circ} \mathrm{C}$ ) on a rotary table $(100 \mathrm{rpm})$. The bacteria were harvested during log phase, centrifuged for $10 \mathrm{~min}$ at $300 \mathrm{~g}$, and resuspended in cold $\left(10^{\circ} \mathrm{C}\right)$ sterile sea water to appropriate concentrations. Bacterial suspensions used for injections were serially diluted and plated to determine actual inoculation doses.

Because the urchins may previously have encountered the marine bacteria, a freshwater bacterium, Aeromonas salmonicida, was also used for some experiments. A. salmonicida is a salmonid fish pathogen, a Gram negative non-motile rod generally not present in the marine environment (although it has rarely been found in marine fish, Evelyn, 1971). These bacteria were grown in tryptic soy broth using methods already described.

\section{Coelomic fluid volume estimates}

Estimation of CF volumes was required for determining the quantity of bacteria to be injected for a specific concentration in the perivisceral coelom. The weight, test diameter, test height, and peristomium diameter were measured for 28 urchins. The CF was then drained through a cut in the peristomium and the volume measured. Each external parameter was regressed on the CF volume. Weight was found to be the best indicator of CF volume $\left(R^{2}=0.96\right)$. The following equation defined the relationship and was used in all experiments:

Coelomic fluid volume $(\mathrm{ml})=0.35 \times$ weight $(\mathrm{g})-4.2$.

\section{Clearance experiments}

Urchins were weighed, CF volumes estimated, and the dose of bacteria calculated for a given final concentration of bacteria in the CF. During experiments, urchins were kept in 20 liter plastic aquaria filled with aerated sea water at $10^{\circ} \mathrm{C}$.

Before injections and sampling, the peristomium was washed several times with cold sterile sea water. Care was taken to avoid tearing tube feet during handling. The bacterial suspension $(0.4-0.6 \mathrm{ml})$ was injected through the peristomial mem- 
brane with a 26 gauge, 0.5 -inch needle and $1 \mathrm{ml}$ tuberculin syringe. Preliminary experiments showed that $40-90$ min were required for even dispersal of bacteria. Because we wanted to sample within that time, half of the inoculum was injected, with the other half injected $180^{\circ}$ from the initial injection site. Coelomic fluid samples $(0.2-0.3 \mathrm{ml})$ were removed with a sterile $26 \mathrm{~g}, 0.5$-inch needle and $1 \mathrm{ml}$ syringe. Samples taken before the injection of bacteria were directly plated for sterility checks. Samples taken after injection of bacteria were serially diluted in sterile sea water and plated by pour plate methods for viable counts. Distinctive colony morphologies, colors, and growth rates were used to help ascertain that these bacteria were those previously injected.

\section{Total and differential coelomocyte cell counts}

At various times after urchins were injected with the marine Gram negative bacteria, or with an equal volume of sterile sea water, CF was removed with a 20 $\mathrm{g}, 1.5$-inch needle into an equal volume of cold anticoagulant $(30 \mathrm{mM}$ EDTA in $0.3 M$ Hepes buffered sea water, after Bertheussen and Seljelid, 1978). Two differential counts were made and averaged using a Brightline hemacytometer. The four major coelomocyte types found in Strongylocentrotus spp. (Johnson, 1969a; Bertheussen and Seljelid, 1978), phagocytes (leukocytes), vibratile cells, and red and colorless spherule (morula) cells, were counted. Total counts were determined by adding the counts for the four cell types.

\section{Humoral factors: In vitro effects of cell-free coelomic fluid} on viable counts of bacteria

Coelomic fluid was removed with a $20 \mathrm{~g}, 1.5$-inch needle or drained out through a cut in the peristomium into a sterile, cold beaker. The CF was immediately filtered by gentle passage through two Millipore prefilters then sterilized using a $0.22 \mu \mathrm{m}$ Millipore filter. Since clotting of CF $\left(30 \mathrm{~min}, 10^{\circ} \mathrm{C}\right)$ before filtration does not seem to affect its bactericidal activity (Wardlaw and Unkles, 1978; Yui, 1982), we routinely filtered before clot formation.

Two $\mathrm{ml}$ of cell-free CF were placed in sterile glass vials. Sterile-filtered artificial sea water (Instant Ocean) or Hepes sea water medium (Bertheussen and Seljelid, 1978) was used as control fluid. Twenty $\mu$ l aliquots of the bacterial suspension were added to each vial, which was then held at $10^{\circ} \mathrm{C}$. Samples $(10$ and $100 \mu \mathrm{l})$ were removed and plated by pour plate methods for viable counts.

\section{Humoral factors: Bacterial agglutinins}

The CF $(5-10 \mathrm{ml})$ was collected through a cut in the peristomium, filtered, added to the first well of a microtiter plate and serially diluted by one-half with $10^{\circ} \mathrm{C}$ artificial sea water (Instant Ocean). The last well was a sea water-only control. An equal volume of bacterial suspension in sea water was added to each well, then the plates were covered and placed on a rotary table $(60 \mathrm{rpm})$ at $10^{\circ} \mathrm{C}$. After 30 min to $20 \mathrm{~h}$ plates were inspected for agglutination.

\section{RESULTS}

\section{Primary clearance}

Gram negative bacteria. Six urchins injected with $3.3 \times 10^{7}$ marine Gram negative bacteria $\mathrm{ml}^{-1}$ of CF rapidly reduced viable counts (v.c.) of bacteria in the CF 
in the first hour post-injection (p.i.) by $95.7 \%$, followed by a period of slower clearance (Fig. 1). Clearance continued after $6 \mathrm{~h}$ (Fig. 2), and bacteria were not detected 4-8 days p.i. To further characterize the initial $90 \mathrm{~min}$ of clearance, four or five samples were removed from each of nine urchins previously injected with $10^{5}-10^{7}$ bacteria $\mathrm{ml}^{-1}$ of CF. Clearance was exponential. Lines were fitted to the log-transformed data using linear regression by calculating independent slopes for each urchin and obtaining a mean and standard error for those slopes. The slopes are equivalent to the "Phagocytic Index" or K value as defined by Biozzi et al. (1953) for particle clearance kinetics in mammals, and Renwrantz and Mohr (1978) for particle clearance in a land snail, Helix. For the first $90 \mathrm{~min}$ of clearance, a $\mathrm{K}$ value of -0.0179 $\pm 0.0016 \log _{10}$ bacteria $\mathrm{min}^{-1}$ was obtained for the Gram negative $\left(R^{2}=0.963\right)$. The slope was not strongly dose dependent (Yui, 1982).

Because of individual differences, primary and secondary clearance rates were determined for the same individual urchins. Injection doses of $10^{6}-10^{7}$ bacteria $\mathrm{ml}^{-1}$ of CF were selected for further experiments because, at those doses, bacteria were:

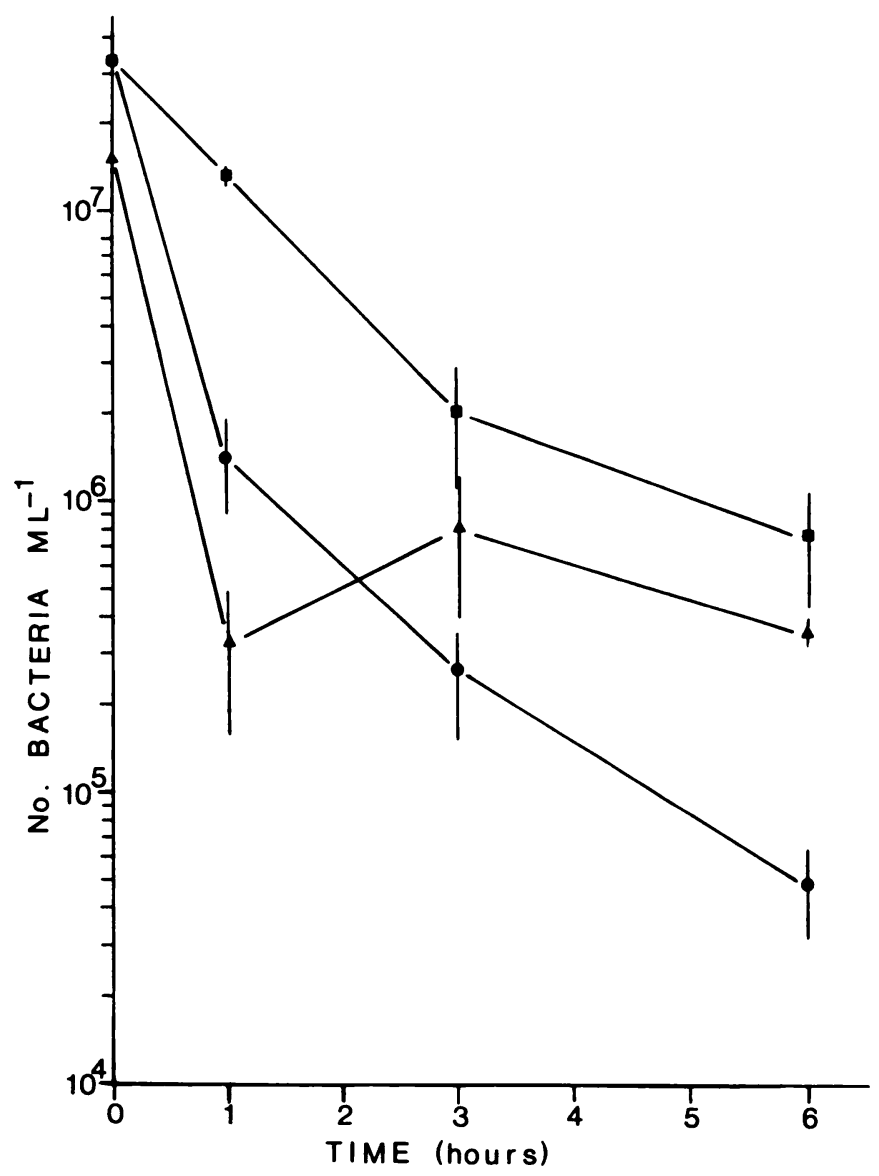

FIGURE 1. Primary clearance of the Gram negative and Gram positive marine bacteria, and Aeromonas salmonicida, sampled at 1,3 , and 6 hours post-injection (mean \pm standard error). $\odot$ Gram negative $(\mathrm{n}=6), \Delta$ Gram positive $(\mathrm{n}=3), \square$ Aeromonas salmonicida $(\mathrm{n}=3)$. 
(a) cleared without mortality or obvious trauma, (b) detectable at high enough levels at 6 and $24 \mathrm{~h}$ p.i. that a decline upon secondary injection was still quantifiable even with small CF sample volumes, and (c) persistent in the CF for a period of 4-8 days. This persistence of viable bacteria in the CF was considered advantageous because sensitization and induction of memory may require a long period of exposure, as with graft rejection. Furthermore, the need for booster injections was precluded.

Gram positive bacteria. A rapid decline $(97.7 \%)$ in v.c. also occurred within 1 $h$ after injection of Gram positive bacteria (Fig. 1). However, unlike the results with the Gram negative bacteria, v.c. were slightly higher at $3 \mathrm{~h}$ with declines continuing to 6 and 24 h p.i. (Fig. 2). Bacteria were not detected 8-12 days p.i. The $\mathrm{K}$ value for the first $90 \mathrm{~min}$ was $-0.0195 \pm 0.0037(\mathrm{n}=3)$, not significantly different from $\mathrm{K}$ for the Gram negative bacteria.

Aeromonas salmonicida. At 1 h p.i., v.c. dropped only $61.5 \%$, a much lower initial rate of clearance than that of the marine bacteria (Fig. 1). Clearance continued at the same rate to $3 \mathrm{~h}$ and more slowly thereafter.

\section{Primary versus secondary clearance}

Because the first and second inoculation doses could not be made identical, the slopes of the lines were calculated from $\log _{10}$-transformed v.c. at time $=0$ to 6 and

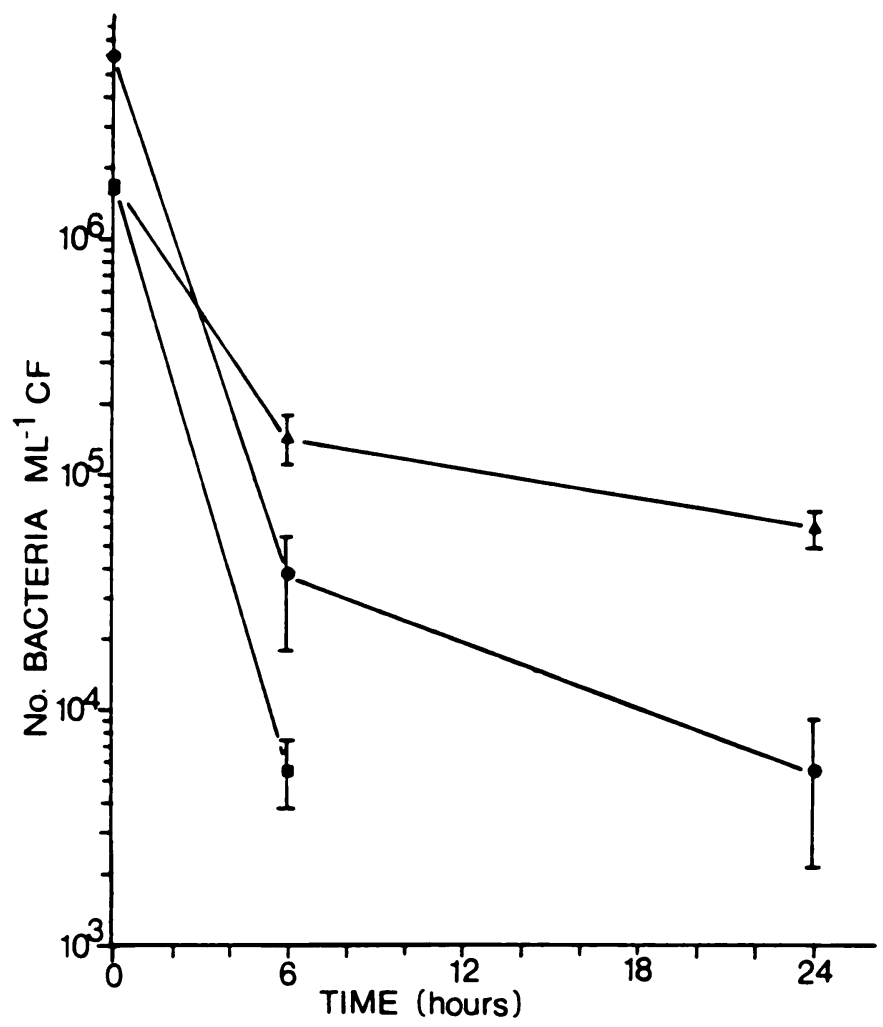

FIGURE 2. Primary clearance of the Gram negative and Gram positive marine bacteria, sampled at 6 and 24 hours post-injection, and Aeromonas salmonicida, sampled at 6 hours post-injection (mean \pm standard error). Gram negative $(n=11), \Delta$ Gram positive $(n=12)$, Aeromonas salmonicida $(n$ $=6)$. 
$24 \mathrm{~h}$. The difference in slope between primary and secondary clearance for each urchin was then calculated and compared to zero (Table I).

Urchins injected with approximately $10^{7}$ bacteria $\mathrm{ml}^{-1}$ of CF were challenged with a similar dose of the same bacteria 9,14 , and 21 days after the first injection of the two marine bacteria, and after 19 days with Aeromonas salmonicida. In no case was the mean difference in slope between primary and secondary clearance significantly different from zero. Even when data from the three injection times were pooled, the mean difference in slope was not significantly different from zero.

\section{Total and differential counts of coelomocytes}

The average number of coelomocytes $\mathrm{ml}^{-1}$ counted from uninjected urchins collected in August and September was $1.0 \pm 0.2 \times 10^{7}(n=6)$. The majority of cells were phagocytes $(67.8 \pm 4.4 \%)$, followed by vibratiles $(16.8 \pm 3.8 \%)$, red spherules $(10.5 \pm 3.1 \%)$, and colorless spherules $(5.0 \pm 1.3 \%)$. These values are similar to those reported for $S$. droebachiensis (Bertheussen and Seljelid, 1978). In October and November, coelomocyte counts were lower, due predominantly to fewer phagocytes (Yui, 1982).

Sea water injected control urchins exhibited a sharp, brief decline in cell numbers during the first hour p.i., followed by rapid recovery to pre-injection values (Fig. 3). After injection of Gram negative bacteria, a sharp decline was seen during the first $1.5 \mathrm{~h}$. Declines continued, more slowly, to about $5 \mathrm{~h}$. The overall drop was from $8.8 \times 10^{6}$ to $6 \times 10^{5}$ coelomocytes $\mathrm{ml}^{-1}$, a $93 \%$ decline.

After injection, all cell types declined (Fig. 3), with a change in the relative proportion of each cell type (Fig. 4). The percentages of phagocytes and red spherule

TABLE I

Mean difference in slope between clearance of primary $\left(1^{\circ}\right)$ and secondary $\left(2^{\circ}\right)$ injections of Gram negative and positive marine bacteria and Aeromonas salmonicida*

\begin{tabular}{|c|c|c|c|c|}
\hline \multirow{2}{*}{$\begin{array}{c}1^{\circ}-2^{\circ} \\
\text { Interval } \\
\text { (days) }\end{array}$} & \multirow{2}{*}{$\begin{array}{c}\text { Sample } \\
\text { time } \\
\text { (hours) }\end{array}$} & \multicolumn{3}{|c|}{ Mean difference in slope $\left(1^{\circ}\right.$ minus $\left.2^{\circ}\right) \bar{x} \pm \operatorname{SD}(n)^{* *}$} \\
\hline & & Gram negative & Gram positive & $\begin{array}{l}\text { Aeromonas } \\
\text { salmonicida }\end{array}$ \\
\hline 9 & $\begin{array}{r}6 \\
24\end{array}$ & $\begin{array}{c}0.083 \pm 0.106 \\
(4) \\
0.006 \pm 0.018 \\
(4)\end{array}$ & $\begin{array}{c}-0.027 \pm 0.108 \\
(4) \\
0.011 \pm 0.011 \\
(4)\end{array}$ & $\begin{array}{l}- \\
-\end{array}$ \\
\hline 14 & $\begin{array}{r}6 \\
24\end{array}$ & $\begin{array}{c}0.038 \pm 0.190 \\
(4) \\
-0.030 \pm 0.051 \\
(3)\end{array}$ & $\begin{array}{c}0.027 \pm 0.078 \\
(4) \\
-0.008 \pm 0.016 \\
(4)\end{array}$ & $\begin{array}{l}- \\
-\end{array}$ \\
\hline 21 & $\begin{array}{r}6 \\
24\end{array}$ & $\begin{array}{c}0.032 \pm 0.182 \\
(4) \\
0.013 \pm 0.024 \\
(4)\end{array}$ & $\begin{array}{c}-0.063 \pm 0.061 \\
(4) \\
-0.020 \pm 0.025 \\
(4)\end{array}$ & - \\
\hline 19 & 6 & - & - & $0.067 \pm 0.090$ \\
\hline
\end{tabular}

* Approximately $1 \times 10^{7}$ bacteria $\mathrm{ml}^{-1}$ of coelomic fluid were injected for each clearance rate determination.

* A negative value indicates a more rapid $2^{\circ}$ rate of clearance, a positive value, a less rapid $2^{\circ}$ rate of clearance. None of these values were significantly different from zero using a Student's $t$-test. 


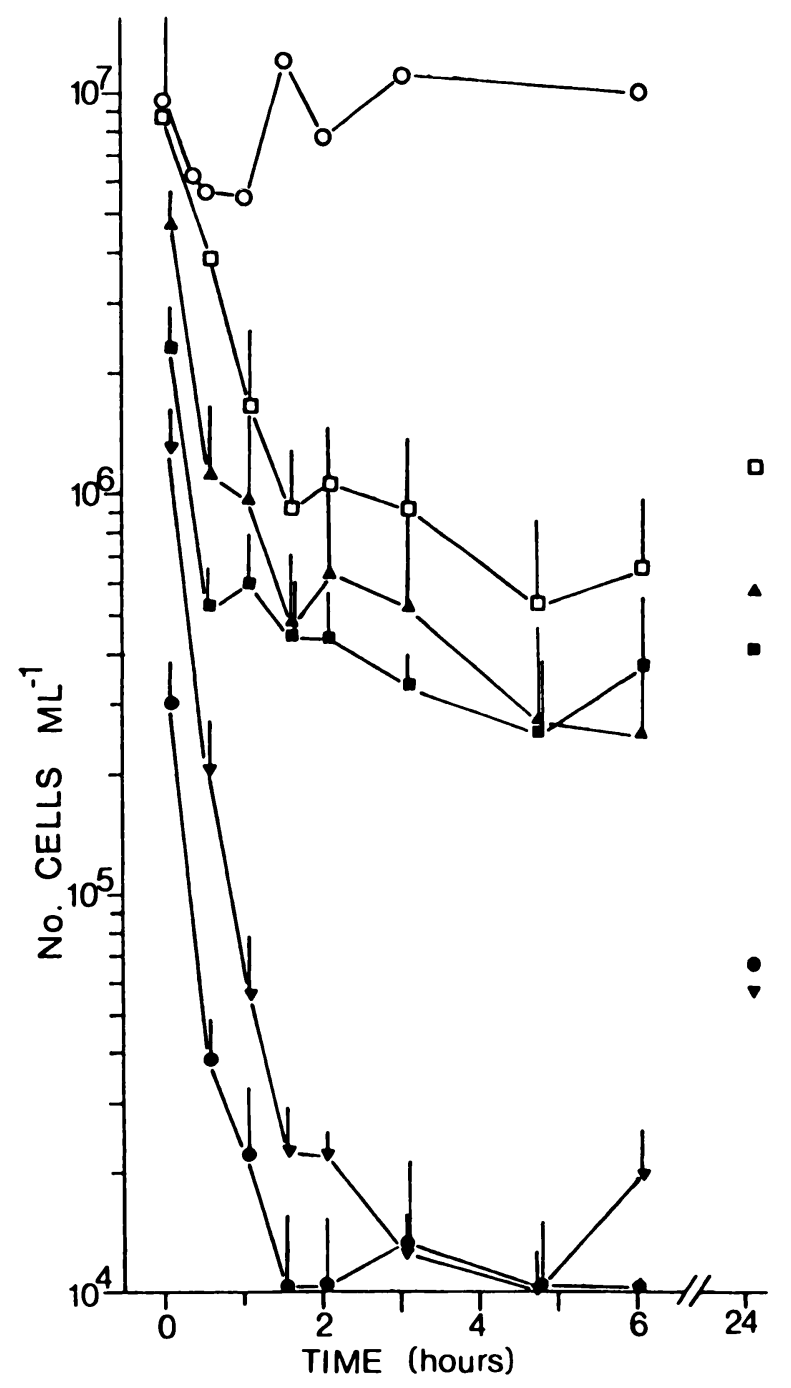

FIGURE 3. Total and differential coelomocyte counts (mean \pm standard error) after injection with $10^{8} \mathrm{Gram}$ negative bacteria $\mathrm{ml}^{-1}$ of coelomic fluid $(\mathrm{n}=3)$. The 24-hour sample was from the only urchin sampled at that time. Also included are the total coelomocyte counts for the sea water-injected control $(\mathbf{n}=1)$. Total coelomocyte counts: $O$ sea water injected, $\square$ bacteria injected; differential coelomocyte counts: $\Delta$ phagocytes, $\square$ vibratiles, $\nabla$ red spherules, $\bullet$ colorless spherules.

cells declined while the percentage of vibratiles increased. The percentage of colorless spherule cells did not change appreciably, although the values were at very low levels throughout. In the one animal sampled at $24 \mathrm{~h}$ p.i., cell counts (Fig. 3) and relative proportions (Fig. 4) were approaching pre-injection values.

Humoral factors: In vitro effects of cell-free coelomic fluid on viable counts of bacteria

Gram negative bacteria. Coelomic fluids from six urchins, three injected 3 days earlier and three uninjected, were tested for their effects on viability of the marine 


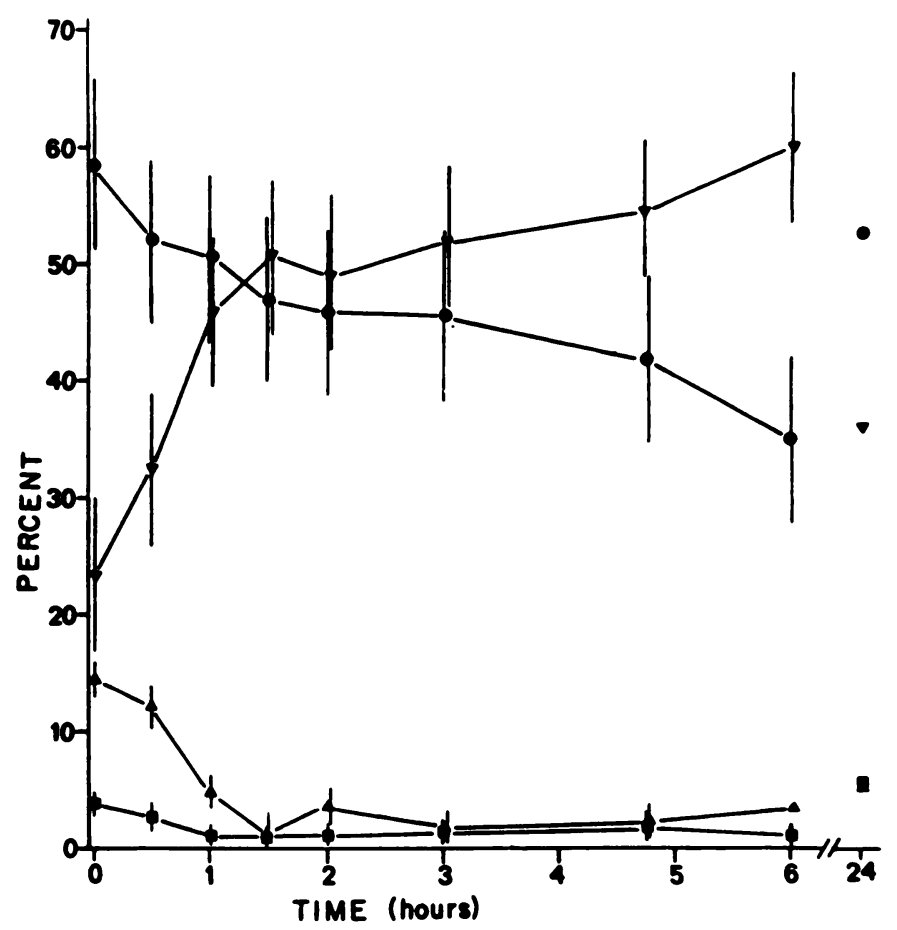

FIGURE 4. Relative proportions (mean $\% \pm$ standard error) of the four coelomocyte types after injection of $10^{7}$ bacteria $\mathrm{ml}^{-1}$ of coelomic fluid $(\mathrm{n}=3)$. The 24-hour sample was from only one of the three urchins. phagocytes, $\nabla$ vibratiles, $\Delta$ red spherules, $\square$ colorless spherules.

Gram negative bacteria. Sea water served as a control. No significant differences were noted between any of the three treatments at 15 and 45 min post-inoculation (one-sided Student's $t$-test) (Fig. 5). Although v.c. were lower in CF from preinjected than in uninjected urchins at $90 \mathrm{~min}$ or $5 \mathrm{~h}$, the differences were not significant. V.c. were significantly lower in the CF from the six urchins than in sea water at 90 $\min (P<0.005)$ and $5 \mathrm{~h}(P<0.01)$.

Gram positive bacteria. The change in v.c. of Gram positive bacteria in CF differed from that of the Gram negative (Fig. 6). V.c. had declined 2.5 orders of magnitude below those of the initial inoculum and the sea water control at $2 \mathrm{~h}$ post-inoculation. Test fluids from each of five urchins exhibited this large decline in v.c. at $2 \mathrm{~h}$ while none of the three controls exhibited a similar response. This result cannot reflect bactericidal activity since counts returned to values not significantly different from sea water controls by $5 \mathrm{~h}$. At $20 \mathrm{~h}$, v.c. in CF were lower than those in sea water ( $P$ $=0.05$ ). Viable counts in CF were quite variable relative to sea water controls. This variability probably reflects differences in amount(s) of humoral factor(s) present in the CF rather than differences due to sampling methods.

\section{Bacterial agglutinins}

Cell-free CF samples from eight urchins were mixed with the Gram negative bacteria and CF samples from four urchins were tested with the Gram positive bacteria, in suspensions ranging from $5 \times 10^{4}$ to $5 \times 10^{8}$ bacteria $\mathrm{ml}^{-1}$. Samples 


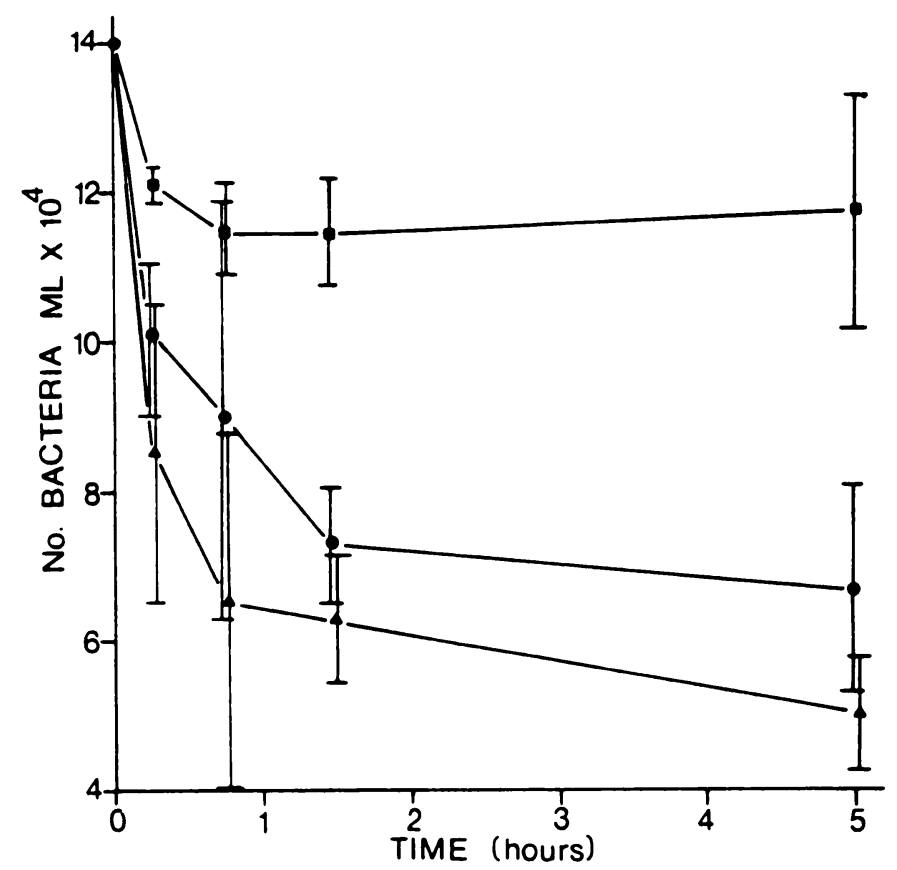

FIGURE 5. Viable counts (mean \pm standard error) for the Gram negative bacteria in sea water and cell-free coelomic fluid from injected and uninjected urchins. $\square$ sea water $(n=3), \bullet$ uninjected $(n=3)$, $\Delta$ injected $(\mathbf{n}=3)$.

were checked at various times from $30 \mathrm{~min}$ to $20 \mathrm{~h}$. Neither of the two bacteria were agglutinated.

\section{Discussion}

\section{Primary clearance}

Clearance from echinoderm coelomic fluid has been reported after the injection of bacteria (Wardlaw and Unkles, 1978; Kaneshiro and Karp, 1980; Bertheussen, 1981), bacteriophage $T_{4}$ (Coffaro, 1978), red blood cells, latex beads and yeast cells (Bertheussen, 1981), xenogeneic cells and carborundum (Reinisch and Bang, 1971), and bovine and human serum albumin (Hilgard and Phillips, 1968). However, the kinetics of particle clearance have not been followed, and the fates of these particles in echinoderms remain unknown.

Strongylocentrotus purpuratus efficiently cleared all three bacteria from its coelomic fluid. Viable counts were reduced $90-99 \%$ in 3-6 h after injection of doses of approximately $10^{6}-10^{7}$ bacteria $\mathrm{ml}^{-1}$ of CF. Clearance occurred in at least two phases, with the rate of clearance of one of the bacteria different from that of the others during each phase. Clearance was approximately exponential for the first 1.5 h p.i. for the Gram negative bacteria. Both marine bacteria were cleared at similar rates over the first $1.5 \mathrm{~h}$ while the initial rate of clearance of $A$. salmonicida was slower than that of the marine bacteria.

The second phase of clearance was slower. However, by $6 \mathrm{~h}$ p.i., $A$. salmonicida had been cleared almost as well as the marine Gram negative bacteria despite the slower initial rate, suggesting a higher rate of clearance after $1 \mathrm{~h}$ compared to the 


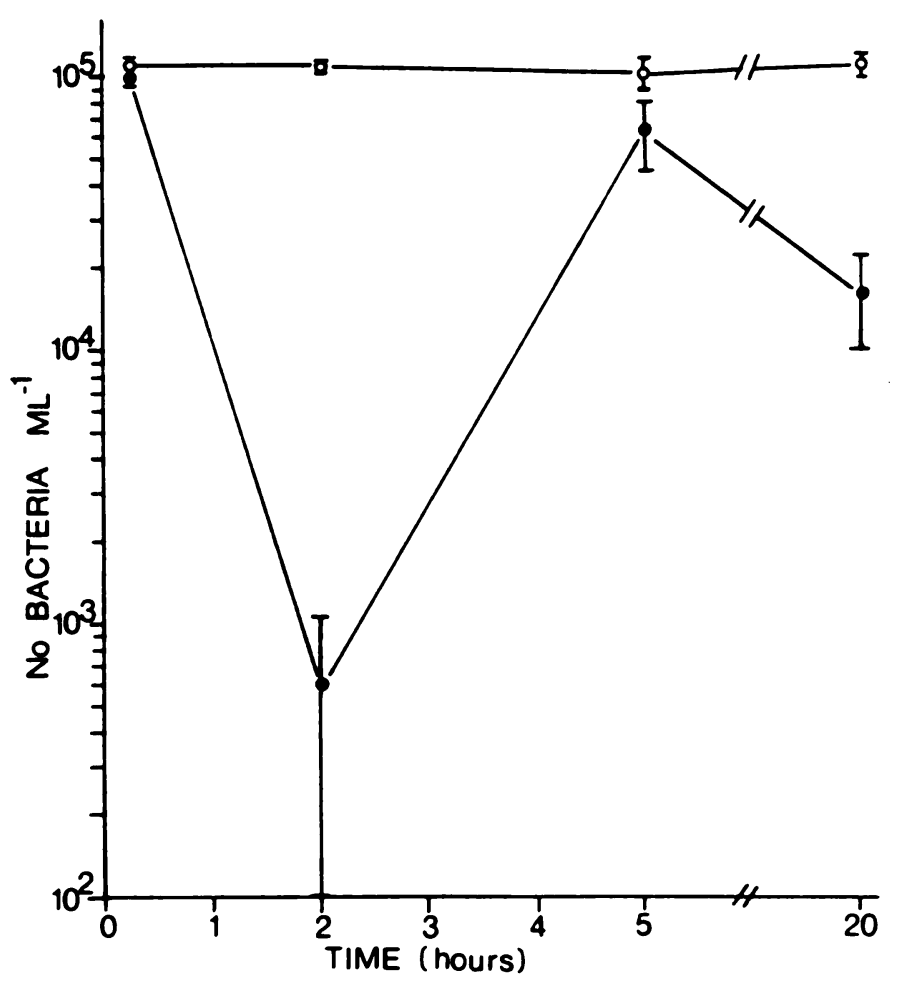

FIGURE 6. Viable counts for the Gram positive bacteria in sea water and cell-free coelomic fluid (mean \pm standard error). $O$ sea water $(n=3)$, $\bullet$ cell-free coelomic fluid $(n=5)$.

other bacteria. The marine Gram positive, on the other hand, had a significantly lower reduction in v.c. at $6 \mathrm{~h}$ p.i. compared with the marine Gram negative bacteria and $A$. salmonicida. At $24 \mathrm{~h}$ the overall percent reduction of Gram positive bacteria was still lower than that of the Gram negative.

The clearance we observed resembles the equivalent process in other invertebrates and in mammals. Generally, the first phase of clearance in mammals is rapid and exponential, with 90-99.9\% reduction in circulating bacteria (Rogers, 1960). This phase is relatively independent of the nature of the microbe, the animal under study, and the subsequent outcome of injection. During the second phase the microbe either persists at lower concentrations or is slowly removed over several hours or days. This phase differs considerably with different bacteria.

Similarly, four mollusc species (Bayne and Kime, 1970; Pauley et al., 1971; Bayne, 1973; van der Knaap et al., 1981) and a crustacean (Smith and Ratcliffe, 1980) cleared $90-99 \%$ of injected bacteria $\left(10^{6}-10^{9}\right.$ bacteria per animal) in the first 2-3 h p.i., with slower subsequent declines after $3 \mathrm{~h}$. In some species Gram positive and Gram negative bacteria may be cleared equally well (Smith and Ratcliffe, 1980), while in others, Gram positives may be cleared more rapidly than Gram negatives (van der Knaap et al., 1981). Gram negative and Gram positive bacteria may be recognized by different coelomocyte subpopulations in the marine annelid, Arenicola marina (Fitzgerald and Ratcliffe, 1982). In Strongylocentrotus spp., Johnson (1969b) noted more active phagocytosis of Gram positive than Gram negative bacteria, in 
contrast with this study. This difference may be due to the different bacteria used or because phagocytosis alone does not determine the overall rate of bacterial clearance.

Total and differential cell counts indicated a 93\% reduction in numbers of all four coelomocyte types accompanying primary clearance of Gram negative bacteria. Similar declines in circulating hemocyte numbers have also been observed in crustaceans (Cornick and Stewart, 1968; Smith and Ratcliffe, 1980), insects (Wittig, 1965; Gagen and Ratcliffe, 1976), molluscs (Bayne and Kime, 1970; Pauley et al., 1971; van der Knapp et al., 1981; Renwrantz et al., 1981), and in leukocyte numbers in mammals (Rogers, 1960).

Clotting, due to aggregation of phagocytes (Johnson, 1969a), no doubt contributes to some of the observed decline in numbers of cells and bacteria. Cellular clots were often observed in coelomic fluid samples which were taken after injection of bacteria. Bertheussen (1981) noted clot formation in $S$. droebachiensis only after injection of bacteria and not after injection of other particles (red blood cells, yeast, latex). Cellular aggregation and/or attachment to epithelia may enhance phagocytosis by providing a substrate for trapping bacteria. Vertebrate leukocytes trap and phagocytose encapsulated bacteria more easily when attached to substrates (Wood, 1960).

Cellular clotting may also explain the observation that red spherule cells declined proportionately with phagocytes while vibratile cells increased proportionately. Red spherules are relatively non-motile and they may therefore be passively caught with aggregating phagocytes as observed in hanging drops (Johnson, 1969a). Although the percentage of non-motile colorless spherules did not appear to change, actual cell counts were very low so changes were difficult to detect. Vibratiles, being highly motile, may extricate themselves from the clots or may be recruited more rapidly from elsewhere, causing the observed increase in relative abundance.

Cell-free coelomic fluid contains one or more humoral factor(s) active against both Gram negative and Gram positive bacteria. To the contrary, Wardlaw and Unkles (1978) found that coelomocytes were required for bactericidal activity. Because the quantity of humoral factor(s) would be limited and not renewable in a cell-free in vitro system, the number of bacteria per given volume of coelomic fluid would be critical in the detection of activity. In addition, observable activity may depend upon the species of bacteria used and the species of echinoderm from which test fluids are obtained.

Declines of 6 to $9 \times 10^{4}$ v.c. $\mathrm{ml}^{-1}$ of $\mathrm{CF}$ from 6 urchins were observed in vitro by $2 \mathrm{~h}$ after inoculation with Gram negative bacteria, enough to account for at least some of the decine observed in vivo. It is possible that the decrease in v.c. was due to agglutination rather than bacterial killing, although agglutination was not detected in this study. Prior injection with bacteria did not accelerate the decline.

Results obtained with Gram positive bacteria in cell-free CF are difficult to explain since agglutinins were not found. Large declines in v.c. were noted in the $2 \mathrm{~h}$ samples from the CF from all 5 urchins tested. These declines could not be explained by bacterial killing because v.c. returned to control levels by $5 \mathrm{~h}$ p.i. and these bacteria do not grow that quickly at $10^{\circ} \mathrm{C}$. These results, however, do correspond with the lower v.c. noted at $1 \mathrm{~h}$ than at $3 \mathrm{~h}$ in in vivo clearance of the Gram positive. Although v.c. in cell-free CF in vitro were not significantly lower than in sea water at $5 \mathrm{~h}$, v.c. at $20 \mathrm{~h}$ were considerably lower than the sea water controls and the initial inoculation dose.

Although bacterial agglutination was not observed, these experiments do not rule out the possibility that agglutinins function in clearance of bacteria. In fact, the 
results of the bactericidal test using the Gram positive suggest that agglutination may occur temporarily at $2 \mathrm{~h}$ p.i. Relative proportions of bacteria to concentration of active molecules in the CF may have been inappropriate for the observation of agglutination.

Differences in the rates of clearance of the three bacteria may depend on (1) differences in specific or non-specific cellular recognition and response, (2) the quantity, rate of release and effectiveness of humoral bactericidal substances, agglutinins, and/or opsonins, and (3) the rate of bacterial reproduction. Based on our studies of in vivo and in vitro primary clearance, it appears that both cellular and humoral factors are involved in bacterial clearance. Clotting and the overall decline of coelomocytes paralleled bacterial clearance. Bacteria were observed in the cellular clots, and within phagocytes after injection (Yui, 1982). Different quantities of CF factor(s) or numbers of responding cells may cause the large individual variation observed between urchins.

The two stages of bacterial clearance in $S$. purpuratus are probably the result of a decline in active cells and/or molecules in the first few hours with further clearance being dependent on the level of cell recruitment or activation and/or release of active molecules.

\section{Primary versus secondary clearance}

Our failure to find accelerated secondary clearance of bacteria is consistent with the few other attempts to induce elevated responses in echinoderms to foreign materials, other than grafts. Coffaro (1978) was unable to elicit accelerated clearance of the bacteriophage $T_{4}$ in Lytechinus pictus. No increase in the rate of foreign protein uptake was detected in $S$. purpuratus after injection of four doses of protein at 18 h, 3 days, 7 days, and 2 months after primary injection (Hilgard and Phillips, 1968). Asterias vulgaris was inoculated with $5 \times 10^{5}$ Arbacia cells six times, with no change in the rate of cell disappearance (Reinisch and Bang, 1971).

Secondary responses to bacteria have been elevated in other phyla, including both deuterostomes (e.g., vertebrates) and protostomes, in which molluscs (see Bayne et al., 1980 for review; Bayne, 1980; van der Knapp, 1980), sipunculids (Evans $e t$ al., 1969), crustaceans (Evans et al., 1968; Acton et al., 1969; McKay and Jenkin, 1969; Stewart and Zwicker, 1974) and insects (Boman et al., 1972; Boman et al., 1974) have yielded positive results. However, in the invertebrate examples, either enhancement has been non-specific or the extent of specificity has not been thoroughly tested, and mechanisms of enhancement are seldom known.

The lack of accelerated secondary clearance in this study can be explained in the following ways:

(1) There is no memory component to bacterial clearance, although memory does appear to exist in responses to grafts and may exist in response to other infectious organisms.

(2) Memory does exist but was undetected due to:

(a) previous exposure to the same or similar bacteria sharing certain surface characteristics or molecules critical for recognition and response, or

(b) lack of sensitivity in detection of memory or sub-optimal enhancement of secondary responses.

Despite such considerations, there is a need to conduct experiments to identify the conditions under which echinoderms will respond optimally to immunologic 
challenge. Without such studies, the mechanisms of echinoderm internal defenses and the evolutionary history of immune responsiveness will remain elusive.

\section{ACKNOWLEDGMENTS}

We thank E. S. Loker and C. A. Boswell for suggestions on the manuscript, and J. A. Longmate for assistance collecting urchins. The research was supported by grants from the Oregon State University Zoology Department Research Fund.

\section{LITERATURE CITED}

ACTON, R. T., P. F. WeINHEIMER, AND E. E. Evans. 1969. A bactericidal system in the lobster Homarus americanus. J. Invert. Pathol. 13: 463-464.

BANG, F. B., AND A. LEMMA. 1962. Bacterial infection and reaction to injury in some echinoderms. $J$. Insect Pathol. 4: 401-414.

BAYNE, C. J. 1973. Internal defense mechanisms of Octopus dofleini. Malacol. Rev. 6: 13-17.

BAYNE, C. J. 1980. Molluscan immunity: Induction of elevated immunity in the land snail (Helix) by injections of bacteria (Pseudomonas aeruginosa). Dev. Comp. Immunol. 4: 43-54.

BAYNE, C. J., AND J. B. KIME. 1970. In vivo removal of bacteria from the hemolymph of the land snail Helix pomatia (Pulmonata: Stylommatophora). Malacol. Rev. 3: 103-113.

BAYNE, C. J., T. SMINIA, AND W. P. W. VAN DER KNAAP. 1980. Immunological memory: Status of molluscan studies. Pp. 57-64 in Phylogeny of Immunological Memory, M. J. Manning, ed. Elsevier/North Holland, Amsterdam.

BERTHEUSSEN, K. 1981. Endocytosis by echinoid phagocytes in vitro. I. Recognition of foreign matter. Dev. Comp. Immunol. 5: 241-250.

BERTHeusSen, K., AND R. SelJelid. 1978. Echinoid phagocytes in vitro. Exp. Cell Res. 111: 401-412.

BIOZZI, G., B. BENACERRAF, AND B. N. HALPERN. 1953. Quantitative study of the reticuloendothelial system. II. A study of the kinetics of the granulopectic activity of the RES in relation to the dose of carbon injected. Br. J. Exp. Pathol. 34: 441-457.

BOMAN, H. G., I. NILSSON, AND B. RASMUSON. 1972. Inducible antibacterial defence system in Drosophila. Nature 237: 232-235.

BOMAN, H. G., I. NILSSON-FAYE, K. PAUL, AND T. RASMUSON. 1974. Insect immunity I. Characteristics of an inducible cell-free antibacterial reaction in hemolymph of Samia cynthia pupae. Infect. Immunol. 10: 136-145.

COFFARO, K. 1978. Clearance of bacteriophage $\mathrm{T}_{4}$ in the sea urchin Lytechinus pictus. J. Invert. Pathol. 32: 384-385.

Coffaro, K. A. 1980. Memory and specificity in the sea urchin, Lytechinus pictus. Pp. 77-80 in Phy logeny of Immunological Memory, M. J. Manning, ed. Elsevier/North Holland, Amsterdam.

COFFARO, K. A., AND R. T. HINEGARDNER. 1977. Immune response in the sea urchin Lytechinus pictus. Science 197: 1389-1390.

COOPER, E. L. 1970. Transplantation immunity in helminths and annelids. Transplant. Proc. 2: 216221.

COOPER, E. L. 1976. Comparative Immunology. Prentice Hall, Inc. 338 pp.

CORNICK, J. W., AND J. E. STEWART. 1968. Interaction of the pathogen Gafjkya homari with natural defense mechanisms of Homarus americanus. J. Fish. Res. Board Can. 25: 695-709.

Evans, E. E., B. Painter, M. L. Evans, P. Weinheimer, AND R. T. Acton. 1968. An induced bactericidin in the spiny lobster, Panulirus argus. Proc. Soc. Exp. Biol. Med. 128: 394-398.

Evans, E. E., P. F. Weinheimer, R. T. ACtON, AND J. E. CuSHING. 1969. Induced bactericidal response in a sipunculid worm. Nature 223: 695 .

EVELYN, T. P. T. 1971. An aberrant strain of the bacterial fish pathogen Aeromonas salmonicida isolated from a marine host, the sablefish (Anoplopoma fimbria), and from two species of cultured Pacific salmon. J. Fish. Res. Board Can. 28: 1629-1634.

FitzGERALD, S. W., AND N. A. RATCLIFFE. 1982. Evidence for the presence of subpopulations of $A r$ enicola marina coelomocytes identified by their selective response toward Gram + ve and Gram - ve bacteria. Dev. Comp. Immunol. 6: 23-34.

GAGEN, S. J., AND N. A. RATCLIFFE. 1976. Studies on the in vivo cellular reactions and fate of injected bacteria in Galleria mellonella and Pieris brassicae larvae. J. Invert. Pathol. 28: 17-24.

hildemann, W. H., R. L. Raison, G. Cheung, C. J. Hull, L. Akaka, and J. Okamoto. 1977. Immunologic specificity and memory in a scleractinian coral. Nature 270: 219-223.

HildemanN, W. H., I. S. JoHnSON, AND P. L. JoKIEL. 1979. Immunocompetence in the lowest metazoan phylum: transplantation immunity in sponges. Science 204: 420-422. 
HildemanN, W. H., E. A. ClARK, AND R. L. RAISON. 1981. Comprehensive Immunogenetics. Elsevier/ North Holland, Amsterdam. $368 \mathrm{pp}$

Hilgard, H. R., AND J. H. PHILlips. 1968. Sea urchin response to foreign substances. Science 161: $1243-1245$.

Johnson, P. T. 1969a. The coelomic elements of sea urchins (Strongylocentrotus) I. The normal coelomocytes; their morphology and dynamics in hanging drops. J. Invert. Pathol. 13: 25-41.

JoHnson, P. T. 1969b. The coelomic elements of sea urchins (Strongylocentrotus). III. In vitro reaction to bacteria. J. Invert. Pathol. 13: 42-62.

Johnson, P. T., P. K. Chien, AND F. A. Chapman. 1970. The coelomic elements of sea urchins (Strongylocentrotus) V. Ultrastructure of leukocytes exposed to bacteria. J. Invert. Pathol. 16: 466-469.

Johnson, P. T., AND F. A. Chapman. 1971. Comparative studies on the in vitro response of bacteria to invertebrate body fluids. III. Stichopus tremulus (sea cucumber) and Dendraster excentricus (sand dollar). J. Invert. Pathol. 17: 94-106.

KANESHIRO, E. S., AND R. D. KARP. 1980. The ultrastructure of coelomocytes of the sea star Dermasterias imbricata. Biol. Bull. 159: 295-310.

KARP, R. D., AND W. H. HILDEMANN. 1976. Specific allograft reactivity in Dermasterias imbricata. Transplantation 22: 434-439.

MANNING, M. J., AND R. J. TURNER. 1976. Comparative Immunobiology. Wiley and Sons. 184 pp.

MARCHALONIS, J. J. 1977. Immunity in Evolution. Harvard University Press. 316 pp.

MCKAY, D., AND C. R. JENKIN. 1969. Immunity in invertebrates. II. Adaptive immunity in the crayfish (Parachaeraps bicarinatus). Immunology 17: 127-137.

Pauley, G. B., S. M. KRASSNer, AND F. A. Chapman. 1971. Bacterial clearance in the California seahare Aplysia californica. J. Invert. Pathol. 18: 227-239.

REINISCH, C. L., AND F. B. BANG. 1971. Cell recognition: Reactions of the seastar (Asterias vulgaris) to the injection of amebocytes of sea urchin (Arbacia punctulata). Cell. Immunol. 2: 496-503.

RENWRANTZ, L., AND W. MOHR. 1978. Opsonizing effect of serum and albumin gland extracts on the elimination of human erythrocytes from the circulation of Helix pomatia. J. Invert. Pathol. 31: 164-170.

RenWrantz, L., W. SChanCke, H. HARM, H. ERL, H. LIEBSCH, AND J. GERCKen. 1981. Discriminative ability and function of the immunobiological recognition system of the snail Helix pomatia. J. Comp. Physiol. 141: 477-488.

Rogers, D. E. 1960. Host mechanisms which act to remove bacteria from the blood stream. Bacteriol. Rev. 24: 50-66.

SMITH, V. J., AND N. A. RATCLIFFE. 1980. Host defense reactions of the shore crab, Carcinus maenas (L): Clearance and distribution of injected test particles. J. Mar. Biol. Assoc. U. K. 60: 89-102.

STEWART, J. E., AND B. M. ZWICKER. 1974. Induction of internal defense mechanisms in the lobster Homarus americanus. Pp. 233-239 in Contemporary Topics in Immunobiology, Vol. 4, E. L. Cooper, ed. Plenum Press.

UNKLES, S. E. 1977. Bacterial flora of the sea urchin Echinus esculentus. Appl. Environ. Microbiol. 34: 347-350.

VAN DER KNAAP, W. P. W. 1980. Recognition of foreigness in the internal defense system of the freshwater gastropod Lymnaea stagnalis. Pp. 91-97 in Aspects of Developmental and Comparative Immunology-I, J. B. Solomon, ed. Pergamon Press, Oxford.

van Der KnaAp, W. P. W., T. Sminia, F. G. M. Kroese, and R. DikKeboOM. 1981. Elimination of bacteria from the circulation of the pond snail Lymnaea stagnalis. Dev. Comp. Immunol. 5: 21-32.

WARDLAW, A. C., AND S. E. UNKLES. 1978. Bactericidal activity of coelomic fluid from the sea urchin Echinus esculentus. J. Invert. Pathol. 32: 25-34.

WITTIG, G. 1965. Phagocytosis of blood cells in healthy and diseased caterpillars. I. Phagocytosis of Bacillus thuringiensis in Pseudaletia unipuncta. J. Invert. Pathol. 7: 474-488.

WooD, W. B. 1960. Phagocytosis, with particular reference to encapsulated bacteria. Bacteriol. Rev. 24: $41-49$.

YUI, M. A. 1982. Bacterial clearance in the sea urchin, Strongylocentrotus purpuratus. M.S. Thesis. Oregon State University, Corvallis. 